\title{
Testing Efficiency On Low Cost Carriers: An Application Of Robust Data Envelopment Analysis
}

\author{
Tüzün Tolga iNAN*
}

Testing Efficiency On Low Cost Carriers: An Application Of Robust Data Envelopment Analysis

\begin{abstract}
This research focuses on low cost carriers by comparing their efficiencies. In total, nine low cost carriers are gathered together for the years between 2003-2013. After designing the data which includes inputs and outputs to measure their efficiency, robustified data envelopment analysis is conducted year by year. Their efficiencies are calculated by listing as a path over time. Their efficiency scores are varied according to years as they are estimated with 1000 time iterated bootstrapped results of data envelopment analysis. First of all, results of variances over time are calculated. Secondly, their coefficient of variations (CV) are calculated too for k-means clustering algorithm. These calculated carriers are separated subgroups as: efficient and consistent, slightly efficient and slighty consistent, neither efficient nor consistent. After the parts of introduction, literature review, description of variable utilizations with methodology and data, the results according to the variables show that depends on assumptions returns to scale.
\end{abstract}

Key Words: Low Cost Carriers, Robust Data Envelopment Analysis, K-Means Clustering.

\begin{abstract}
Düşük Maliyetli Taşıyıcılarda Verimliliğin Test Edilmesi: Sağlamlaştırımış Veri Zarflama Analizi Uygulaması

Özet

$\mathrm{Bu}$ araştırma, verimlilikleri karşılaştırarak düşük maliyetli taşıyıcılara odaklanmaktadır. Bu makalede 2003-2013 yıllan arasında toplam dokuz adet düşük maliyetli taşıyıcı bir araya getirilmiştir. Verimliliği ölçmek için girdi ve çıktıları içeren veriler tasarlandıktan sonra, her yıl sağlamlaştırımış veri zarflama analizi yapılmaktadır. Etkinlikler zaman içinde gösterilen aşamalar listelenerek hesaplanır. Verimlilik puanları, veri zarflama analizinin 1000 kez yinelenen önyüklenmiş sonuçlarıyla tahmin edildiği şekilde yıllara göre değişmektedir. Illk olarak, her şeyden önce zaman içindeki değişikliklerin sonuçları hesaplanır. İkinci olarak, varyasyon katsayıları (CV), k-aracı kümeleme algoritması için ayrı ayrı hesaplanır. Bu hesaplanan taşıyıcılar alt gruplara ayrilır. Bu alt gruplar; verimli ve tutarlı, hafif verimli ve hafif tutarlı, ne verimli ne de tutarlı olarak sınıflandırılır. Sırasıyla; giriş, literatür taraması, metodoloji ve verilerle değişken kullanımlarının tanımlanmasından sonra, analiz üzerinde gösterilen değişkenlere göre sonuçlar varsayımlara bağlı olunduğunu göstermektedir.
\end{abstract}

Anahtar Kelimeler: Düşük Maliyetli Taşıyıcılar, Sağlamlaştırımış Veri Zarflama Analizi, K-Aracı Küme Algoritması

\section{Introduction}

Civil Aviation History has seven sections including five fundamental periods. These are; The Pioneer Era (1903-1914), World War I (1914-1918), Between the World Wars (1918-1939), World War II (1939-1945), The Postwar Era (1945-1979), the Digital Age (1980-present) and also the 21st

*Tüzün Tolga INAN, Dr.Öğr.Üyesi., İstanbul Gelişim Üniversitesi, Havacılık Yönetimi İngilizce Bölümü, tttinan@gelisim.edu.tr; ORCID ID orcid.org / 0000-0002-5937-9217 
century as a second part of the digital age (Brown, 1980). Civil Aviation History was started with the first engine flight performed by Wright Brothers in 17 December 1903 After this event, the Pioneer Era was started. In this era the progress of practical aeroplanes, airships and their early implementation rerlated with balloons, kites for private sport and military access were examined. In the World War I Era, airmen were formed as modern-day chevaliers for doing individual fights with their hostiles. In between the World Wars Era, people saw grand expansions in aircraft technology. The age of the grand harsh zeppelins came and went. In World War II Era, people saw a grand increment in the speed of progress and manufacture, not only of aircraft but also the incorporated flight-based weapon surrender frameworks. In the Postwar Era, commercial aviation expanded quickly accessing usually ex-military aircraft to carry people and freight. In this era, hub and spoke concepts were passed on to practice. Hub concept means the central airport which is used by the countries flag carrier airline. Spoke means the connection destinations which are done from the hub. Civil Aviation Industry gained speed at the end of the Postwar Era. In 1970's customs application passed on to practice. Before 1970's safety and security applications were not important enough. After the customs application, deregulation, liberalization, hub and spoke (HS), freedom to enter and exit markets, propose networks and range fares and levels of service issues gained importance (Adler and Golany, 2001). In the Digital Age Era, anymore was reformation advancement for to perform in flight speeds, journeys and substance technology. In the beginning of 21st century, civil aviation has observed growing attention in fuel savings and fuel variation, as well as low cost airlines and modern facilities (Oum and Yu, 1998). In this period, wet lease and dry lease concepts were also passed on to practice. Wet lease means hiring an aircraft with itself, its crew and fuel. Dry lease means hiring an aircraft with itself only. Besides this, financial leasing concept was pervaded in this period. Before the beginning of 21st century, it is obvious that the airline industry has just came by strategic alliances like mergers, acquisitions and joint ventures which foster regional (or continental) hubbing as segment of a global airline network (Hsu, Chao and Huang, 2013).

There were published articles related with low cost carriers' data envelopment analysis with the evaluation of operational and technical efficiency levels, however, there are insufficient information about low cost carriers' performance efficiency levels. In researches, one or two airlines were analyzed but nine airlines were not examined with the efficiency levels of data envelopment analysis. So, this research can be a milestone for the multiple review of low cost carriers with their performance efficiency levels.

\section{Literature Review}

Full Service Carrier (or Legacy Carrier) is the old and the long-established model for civil aviation industry. Since the beginning of passenger transportation with commercial aircrafts, this model has carried out. In this model, the ticket prices and the comfort level provided for the passengers are in high level. Before the beginning of 1990's, this model is monopoly because of this all passengers can prefer solely this model for civil air transportation. 
The majority of Europe's big scale airlines were established by the states or with the support of the state. These are called full service, legacy and national flag carriers. These carriers are determined as symbols of independence and defined wholly as national prestige. They are also used for economic purposes. These economic purposes are such as; providing employment, offering services to small scale and remote countries which private airlines do not want to go because of can not making a profit. In some states these kind of airlines are financed by the states, however in another states these kind of airlines are partly supported by states and the other part is privatized. Generally the privatization ratio is $51 \%$ because of being able to make management decisions.

However with the influence of low cost transportation model in the beginning of 1990's, ticket prices and the comfort level provided for passengers were declined and by this way passenger traffic has been well documented for passengers for to get rid of monopoly air transportation. Yet, this trend started with the result in a decrease of 34 per cent in the mean prices at 15 destinations in the period of 1984-1985. This period was a documented preparation for the transition of full service carrier strategy to low cost transportation strategy (Whinston and Collins, 1992).

In addition to the period of 1984-1985, Bailey, Graham and Kaplan (1985) applicated 19801981 data with Strassmann (1990) applicated 1980 data, both discovered that newly-certified carriers had a negative effect on US domestic efficiencies, but with the 1984-1985 period this negative effect turned into to positive effect in US domestic efficiencies (Whinston and Collins, 1992).

This positive impact of low cost carriers were examined from the United States Department of Transportation with the examination of Southwest Airlines in an issue of California markets. Conclusion of this examination showed that Soutwest Airlines' entrance to market decreased the ticket prices 55 per cent with a sixfold increment in passenger traffic (Bennett and Craun, 1993). At last of the analysis, Windle and Dresner applicated a data set in a period of 1991-1994. In this data set, they gained that the entrance of Southwest Airlines concluded with an average price decrease of 48 per cent and a traffic increment of 200 per cent (Windle and Dresner, 1995).

The uppermost incentive of this research paper bases from three cases that took into action by matching the global airline industry airlines between the years 2003 and 2013 . There are many researches related with the modelling of airline efficiency and performance using with a variety of approaches. These approaches have been sorted from Caves et al. $(1984,1979)$ past days to nowadays. The Civil Aviation industry has often been criticized because of the having higher production costs. Besides this, especially US airlines compared their efficiencies and demonstrate that deregulated US airlines are more efficient than their highly regulated equivalents (Windle, 1991; Good et al., 1993, 1995).

The deregulation forms of civil aviation increased competition, lowered ticket prices, provide substantial benefits for passengers and enlarge productivity for the industry. The provable effects of prosperous US deregulation and continuing inefficiency in the industry may have influenced the 
European Commission to start certain reforms to sustain competition and besides that enhance the efficiency and productivity of the European Airlines (Bailey, 1985; Kasper, 1988).

This duration is named liberalization. In 1987 following reform covers were introduced to maintain flexibilities in pricing, capacity sharing and market access. The first liberalization package related with limited freedom to compete on cheap prices by offering different options for busier routes and less restrictive capacity sharing agreement decisions have redounded the operation capacity up to 60\% (Vincent and Stasinopoulos, 1990).

The second package of liberalization allowed flexible regulations about specifying ticket prices and improving market access by presenting different options to passengers. Deep discounts were reduced the ticket prices approximately $30 \%$ since 1987 and as a whole $45 \%$. Restrictions imposed on capacity shares were eliminated by January 1993 by the date of the single market for European Aviation (Stasinopoulos, 1992). With the European Community policies for the single market compelled third liberalization package with more rigid effects. Airlines set their own tariffs freely against the savage pricing. The opening of entrance to whole all intra-community gauges, for instance the cabotage rights was completed in 1997 (Stasinopoulos, 1993).

During the early stage of liberalization which were processed by some privatization applications, European Airlines analyzed the recent performance measures and evaluate the factors of performance. The co-existence of public and private airlines in a competitive environment analyzes and by the way private ownership of airlines gain higher efficiency than public airlines. There have other elements effects efficiency level such as consolidation or service competition which can define the diversity in efficiency. The concept of the relative efficiency of public and private airlines has continually attracted economists. Various academicians and policy makers prepare their evaluations for privatization and deregulation for the technical efficiency diversification between the two ownership types. Technical efficiency shows the ability of gain maximum output from a variety of given outputs. Furthermore, it is generally esteemed that the technical efficiency of private airlines are much higher than the public ones (Fethi et al., 2000).

There are several theories to effect the consensus such as property rights, public choice and regulation options. The first theory which is related with the term of property rights could be related with the researchers of Alchian (1965) and Alchian and Demsetz (1972), the weakining of property rights in public airlines guide to observing problems and reverse behavioral incentives by composing mismanagement and inefficiency. The second theory that is about the theorists who selects public system like Niskanen (2017) discuss with public industry managers and reach a consensus about to operate under inadequate competitive environments for maximizing the industry's budgets. This self-interested behavior diminishing cost lessen incentives. The third and the final theory recommends that regulatory authorities are seized by exclusive attention communities and subserve the producers attention more than the public ones. The total of three theories with a final decision of finalize that private airlines are more efficient than the public ones. In the 
beginning of 1970's, the private airlines' system is not analyzed in an effective way. However after 1970 's private airlines' system is being understood more efficient than public ones. Beginning with 1980 's, mixed system which related with various industry types were existed (Millward et al., 1983; Boardman and Vining, 1989).

In the aspect of numerous samples, researches about the airlines efficiency and productivity has not an empirical question which requires industry particular researches. By this way, data envelopment analysis (DEA) is a technique for evaluating the efficiency of production determinations implemented in private industry. Investigations established at the production boundary that are appointed at a value fewer than unity, so near the boundary are appointed a value less than unity. So, efficiency and productivity are significant subjects to specify the performance of airlines. There are two objectives about the policy changes in airlines. First one is to measure the effects of policy change to determine the strong distinctions in the performance of airlines depending on the degree to which they have answered. The second objective is to ensure the nearest envelopment of the monitored data for this aim about the improvement of broad sequence of Data Envelopment Analysis (DEA) and Stochastic Frontier Analysis (SFA) models. The impasse of model selection counts on commerce off between minimum determinations which favors DEA and authorizing for stochastic error in evaluating airline efficiency which favors SFA.

The years of 1970's, 1980's and 1990's researches focused on the first stage of initial performance outcomes about liberalization improvements in the European Airlines industry. In second stage of this evaluation, efficiency differences between airlines are defined with the recent strategies. In third stage the attributes of efficiency measures are latented. Especially, the probable factors of efficiency in the European Airlines industry is expressed. The airlines which forms the model are shortly described in stage four. The empirical consequences are recorded in stage five. At last, the examination of the years between 1970's to 1990's are finalized.

In the years of 2000's, the systems which applied in airlines have been modernized. For example, Barros and Peypoch (2009) took into account the efficiency of European Airlines between 2000 and 2005. One addition to their research was the use of Simar and Wilson (2007)'s two-stage approach, which examined the impact environmental variables on efficiency. Bhadra (2009) surveyed the performance of US airlines over the period 1985-2006, however by using a Tobit model which Simar and Wilson (2007) discussed earlier required several restrictions. At last, Barbot et al. (2008) specified the performance of 49 international airlines including Low Cost Carriers in 2005 by using Simar and Wilson (2007)'s model.

In the previous years the theoretical researches of Land, Lovell and Thore (1993, p. 541-554) and Olesen and Petersen (1995, p. 442-457) suggested the exciting possibility of stochastic data envelopment analysis (SDEA). This can be commented as an aspect of authorizing for stochastic error in the regular DEA model. The first concept related with this research is to implementation stage of the attempt of liberalization in the European Airline industry over the term 1991-1995. 
Specifically, it is discovered the LLT model which uses the limitations in an envelopment form of DEA as exposed to alter.

The second concept about the research is to identify the observed effects of airline market liberalization that concluded in efficiency alterations both in level and distribution for the airlines concerned. All of the investigations are used as deterministic for the alterations that are featured to notional inefficiency for simple to overcharge the effect of policy alterations in the short period. Hereby it is sought for the SDEA model, whether it can be successfully implemented decreasing the clearance of the policy consequences. The inquiry is provided that any powerful consequences will stay related with the effect of the liberalization. Subsequently, it is maintained the intimate envelopment of the data that run with the SDEA model.

Besides the examination of different models about data envelopment analysis, another significant subject is specifying the hub. Hub means the center airport of a country which is used by the flag carrier airline. When choosing the hub, demand and network problems are important. Furthermore, airport quality factors are another prominent issues which effect the choice of hub. Costs of operation is a major concept which includes delay data, runway capacity, local labor potency costs and the credibility of airport traffic control. Quality of airport services about various airlines are used to operate a methodology capable of ranking airports concerned with their quality grade. The methodology selected was data envelopment analysis (DEA) that can examine airlines with manifold inputs and outputs meanwhile.

In the first sample of efficiency research paper handled the approach first presented in Simar and Wilson (2007). In the first part, DEA scores are reproduced for 43 international airlines in 2017. In the second part, it is setbacked these estimated outputs on environmental variants using a double bootstrap truncated regression model. Determination of these environmental variants effect on efficiency related with the importance of airline management to define prevailing performance important strategies.

The purpose of second sample of efficiency research paper was triplicated. First of all, it is identified if there is a proof related with efficiency in mainstream airlines consequence of the events between the years 2003 and 2013 are established in the research paper. Secondly, it is stated the efficiency levels of low cost carriers with the full service (legacy) carriers include international ones. At final, it is forecasted the primary economic driver of the environmental variants underlying about the measures which includes technical efficiency.

The purpose of the third and the last sample of efficiency research paper is related with the years of 2000's about the remaining research paper itself contains five main functions. In the first part of this main functions, it is prepared a literature research related with the concept of data envelopment analysis. Part two puts forward the empirical methodology. Part three expresses the inputs and outputs such as the environmental variants, performance parameters and the restrictions of the selected data. In part four, it is debated the technical measurement of efficiency 
scores and the outcomes of the second stage regression analysis. Part 5 concludes the research article (Lee and Worthington, 2014) .

\section{Variable Utilizations}

In this research paper it is allocated two types of data. These are: subjective data and objective data. The primary origin of subjective data is an examination which includes airlines annual reports between the years of 2003 and 2013. The objective data is obtained from airline's inputs and outputs. These inputs and outputs are identified as performance parameters and they are partitioned as operating parameters and financial parameters. (Garc' ia and Cadarso, 2017).

\subsection{Performance Parameters}

PC: The number of passengers carried.

\subsubsection{Input Parameters}

These parameters indicate air traffic patterns and airline performance.

They form inputs of objective the data.

ASK: Available seat kilometers.

PLF: Passenger Load Factor (also means LF).

PTK: Passenger Tonne Kilometers Thousands.

The abbreviations are formed from the performance parameters such as ASK, PC (RPK) and PC (RPK) / ASK = Passenger Load Factor (PLF) or Load Factor (LF).

It is used four parameters in this research. These are the number of passengers carried (PC), passenger tonne kilometer performed in thousands (PTK), available seat kilometers (ASK) and passenger load factor (PLF). The first variable PC is an output and assumed as measuring the performance of any carrier. So, the other variables; PTK, ASK and PLF are functionalized as inputs used by airlines.

\section{Methodology and Data}

In order to calculate efficiency over time, the data is utilized from IATA and airlines' annual reports for the time in between 2003 and 2013, namely 11 years for nine low cost carriers. Data consist of four variables as such: Passengers carried (PC), passenger tonne kilometer performed in thousands (PTK), available seat kilometers (ASK) and passenger load factor (PLF). The first variable is used as output (PC) which is assumed as well-measurement of performance of any carrier. So, the latter three, PTK, ASK and PLF are functionalized as inputs used by airlines.

Since, only PLF are ranged from 0 to 1 as a percentage, the others are huge numbers that can not be suitable to run into any parametric methodology. Regardless of looking to the results of 
normality testing on these parameters (also it may be useless for a time serie), these variables along with PLF are formed into natural logarithm to scale them in parallel with PLF.

First, after looking the descriptive statistics of variables, Pearson's correlation coefficients are calculated among variables to draw the relationship in between variables by pairwise to prevent from a perfect collinearity among them. Second, data envelopment analysis (DEA) is run to estimate their efficiency, however, it is done with a very basic bootstrapping algorithm which allows to look confidence intervals of coefficients of efficiencies. In order to enhance and go deeper, all DEA processes are run by assuming returns to scale as constant, variable or non-decreasing. However, it is not aimed to assume output oriented in any DEA calculation, so each efficiency coefficients are calculated by assuming input oriented. Third, later than calculation of efficiency coefficients over years, coefficient of variations $\left(\mathrm{CV}^{1}\right)$ are calculated among years in order to examine whether their efficiency pattern is either consistent or variated. Since CVs of carriers are strongly dependent on their mean efficiency, it also gives a clear insight about the balance in between efficiency score and its volatility among years. The mean is placed as denominator, the variance is at nominator, so if a firm has highly volatile in terms of its efficiency while it also has lower efficiency score, CV will be greater. Efficiency will be in 0 and 1 which indicates perfect efficiency, CV will be equal to volatility of efficiency. So lower CV is better.

Lastly, carriers' CV are grouped into three by using k-means clustering algorithm which is centroid based one. The first group is centered around lower efficiency but higher volatility, the second one is balanced in between slight efficiency and slight variation, the last group has higher efficiency and lower variation.

\section{Results}

The variables used in this study, PC, PTK, ASK and PLF are transformed into their natural logarithm in order to scale them in a lower range and to linearize them against both extreme values (outliers) and strong volatility. Descriptive statistics of the data are given Table 1 below:

\footnotetext{
${ }^{1} C V_{i}=\sigma_{i} / X_{i}$, the ratio of standard deviation to mean in which $\mathrm{i}=\{1, . ., 9\}$.
} 
Eskişehir Osmangazi Üniversitesi Sosyal Bilimler Dergisi

Table 1. Descriptives for Data

\begin{tabular}{lcccccc}
\hline Statistic & $N$ & Min & Median & Mean & Max & St. Dev. \\
\hline PC & 99 & 14.6000 & 16.2900 & 16.6000 & 18.5600 & 1.0510 \\
PTK & 99 & 11.8100 & 14.2300 & 14.2600 & 16.3900 & 1.2000 \\
ASK & 99 & 14.6600 & 16.8300 & 16.9300 & 19.0100 & 1.1480 \\
PLF & 99 & -0.5127 & -0.2298 & -0.2630 & -0.0910 & 0.0945 \\
\hline
\end{tabular}

All variables are taken as natural logarithm.

As given median and mean are so close to each other, it can be seen the data are a bit normalized. In order to prevent the collinearity problem, pairwise correlations are estimated as following in Table 2: The highest correlation coefficient is observed in between PTK and ASK. There is no perfect collinearity in Table 2, so they can be included into DEA together to calculate efficiencies. To get these coefficients, DEA is run under input oriented approaches with three assumptions in terms of returns to scale as constant, variant and non-decreasing.

Table 2. Pearson Correlations of variables

\begin{tabular}{cccc}
\hline \hline & $P C$ & $P T K$ & $A S K$ \\
\hline PC PTK & & & \\
& $0.9496^{* * *}$ & & \\
ASK & $0.9593^{* * *}$ & $0.9962^{* * *}$ & \\
PLF & $0.3472^{* * *}$ & $0.4815^{* * *}$ & $0.4206^{* * *}$
\end{tabular}

Significance levels $*{ }^{* *}$ and ${ }^{* * *}$ denote $.10, .05, .01$ respectively. 


\section{Tüzün Tolga INAN}

Figure 1. Efficiencies over 11 years w/ CRTS

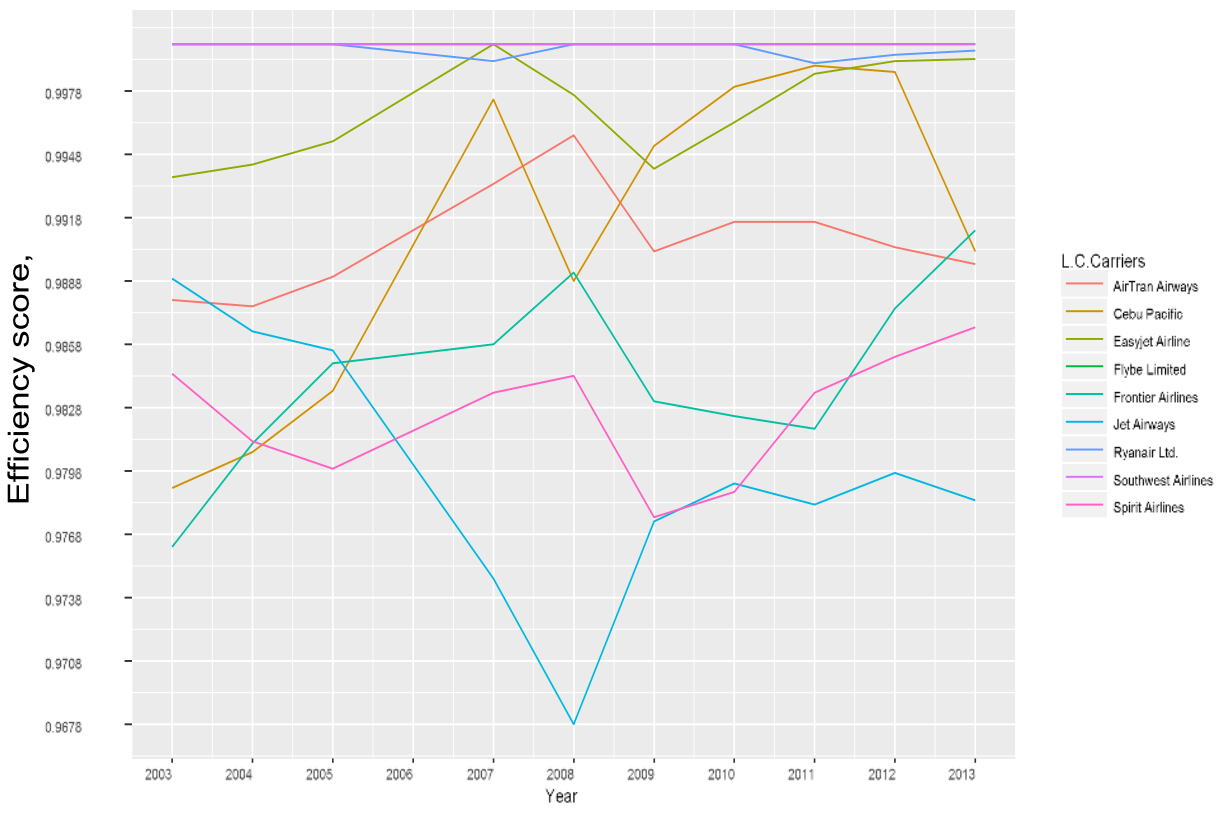

In Figures 1, 2 and 3, firms are drawn respectively the efficiency scores according to constant, variant or non-decreasing returns to scale assumptions.

The results are shown in Appendix 3. 
Eskişehir Osmangazi Üniversitesi Sosyal Bilimler Dergisi

Figure 2. Efficiencies over 11 years w/ VRTS

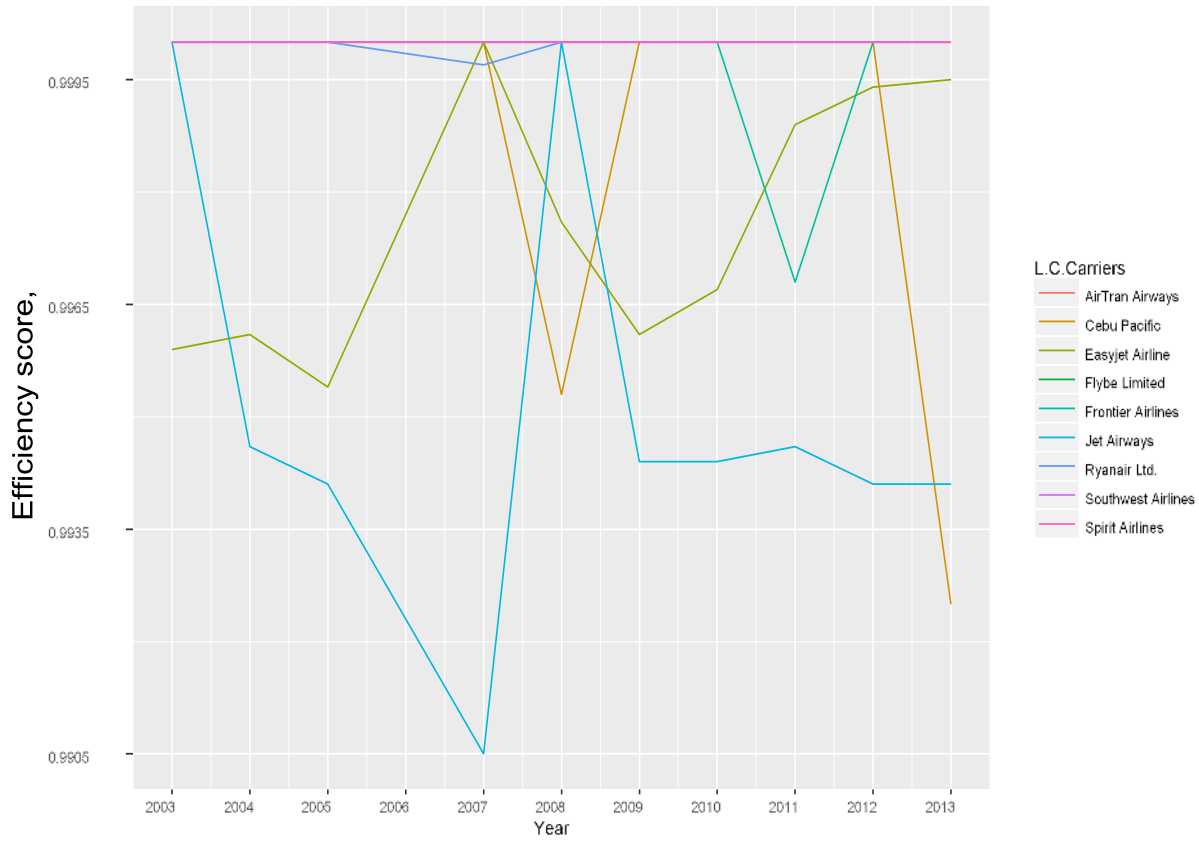

Figure 3. Efficiencies over 11 years w/ NRTS

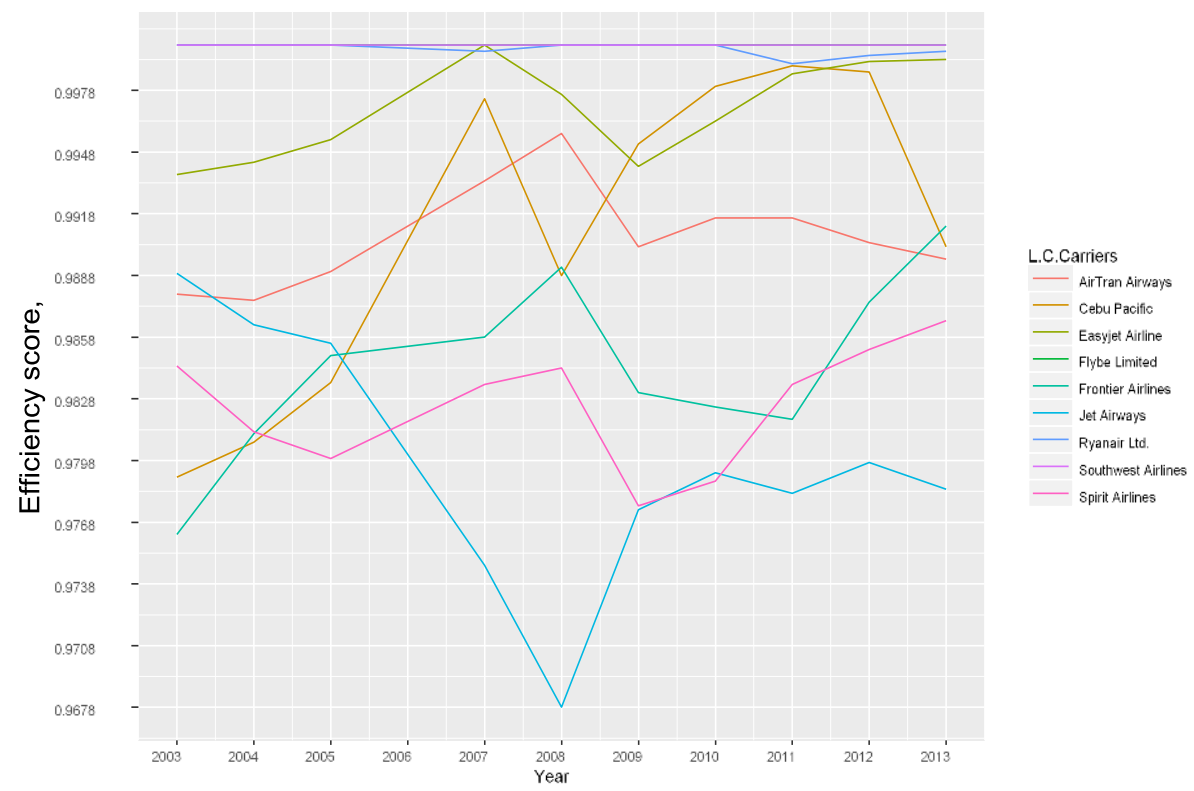


As the results clearly show, the figures drawing the pattern of efficiencies over time are similar in constant and non-decreasing returns to scale (Figure 1 and 3). Except seven low cost carriers, two of them outperform and get the highest efficiency scores over time. Rest of them show at least a slight decreases in one or more years. In this study, it is also focused on the variations in efficiency scores over time and their mean efficiencies. In order to do so, their variances and means are calculated over their estimated efficiency scores. By using the formula of coefficient of variation, it is searched for the patterns whether it persists over time as both fluctuated and consistent or not. As CV is less vulnerable to consistency, it can be used for to look at stabilization. CV is damaged if the airline is less efficient. Again, CV decreases if the airline has a volatile efficiency scores over time since square root of variance decreases. Later, their CVs are clustered by using centroid-based clustering algorithm, k-means clustering. Just because the number of clusters does not lead to provide good results if it is higher or lower than 3 , it is assumed as 3 . The clusters can be named by authors as following:

The clusters are:

1. superior, that is the airline has higher efficiency scores but less volatile.

2. slightly good, that is the airline has either slightly good efficiency scores or slightly volatility over time.

3. worst, that is the airline has relatively lower efficiency scores while it is so volatile over time. 
Eskişehir Osmangazi Üniversitesi Sosyal Bilimler Dergisi

Figure 4. K-means clusters of 9 L.C.C. w/ CRTS

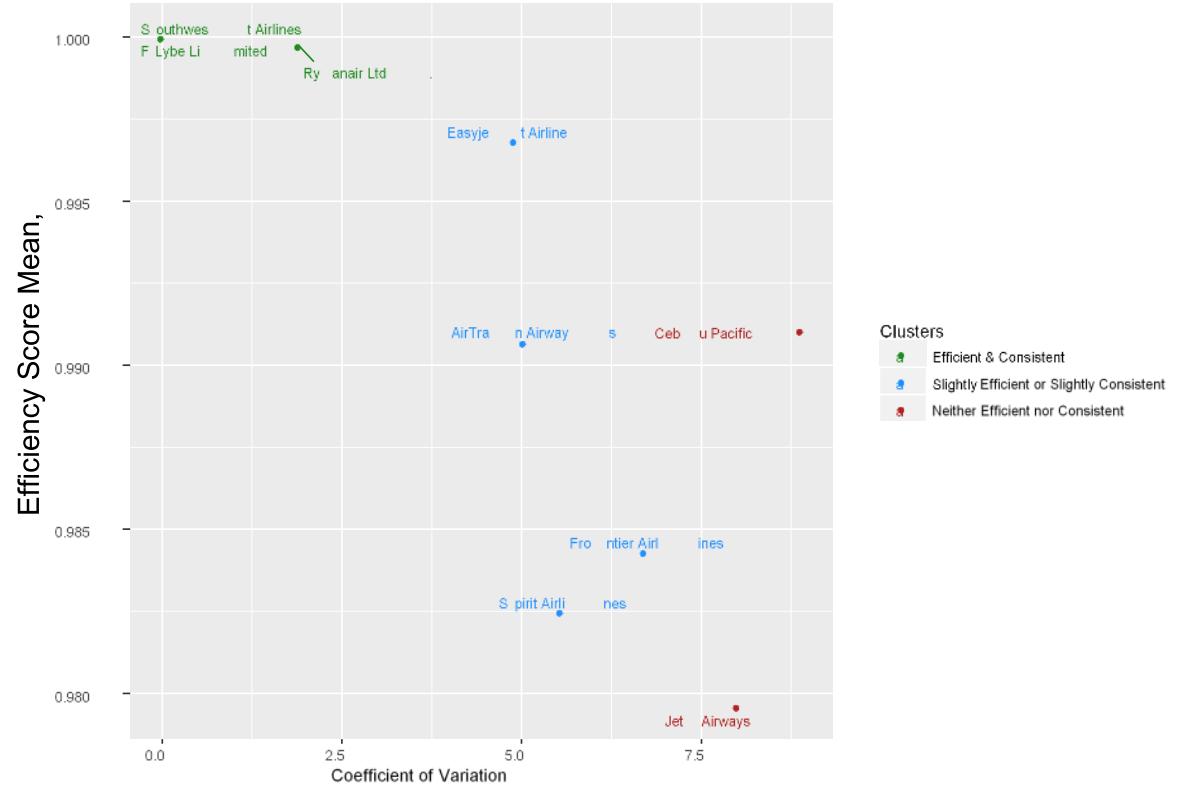

Figure 5. K-means clusters of 9 L.C.C. w/ vRTS

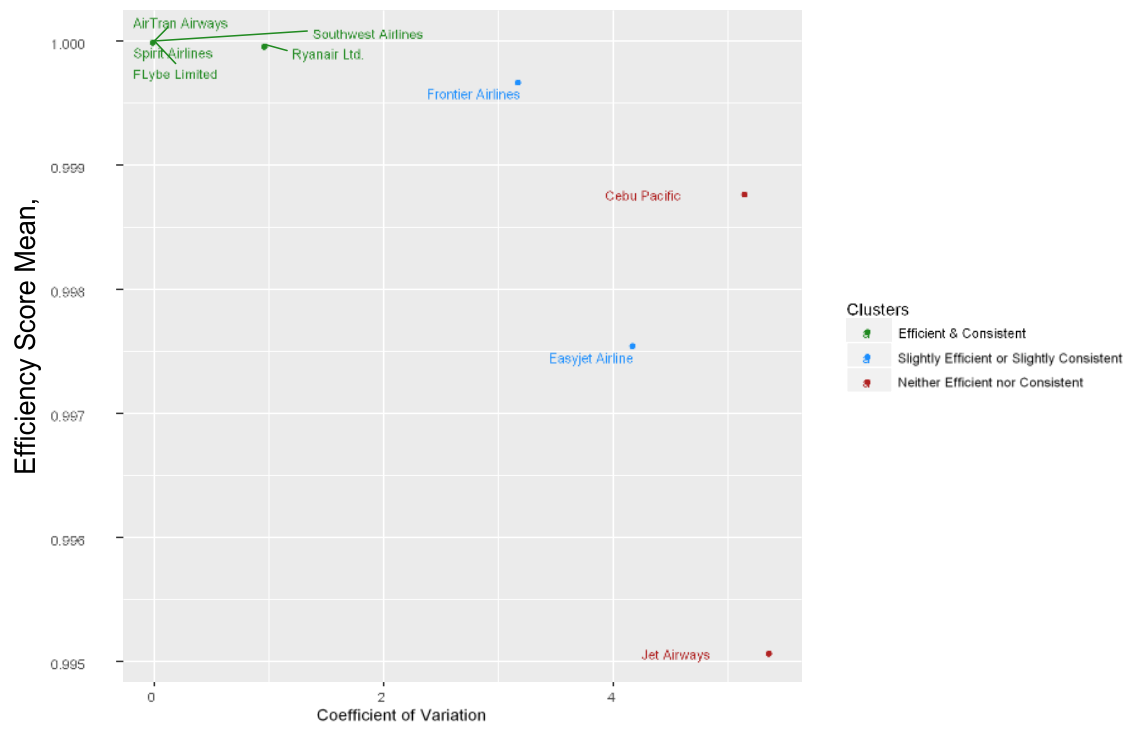


Figure 6. K-means clusters of 9 L.C.C. w/ NRTS

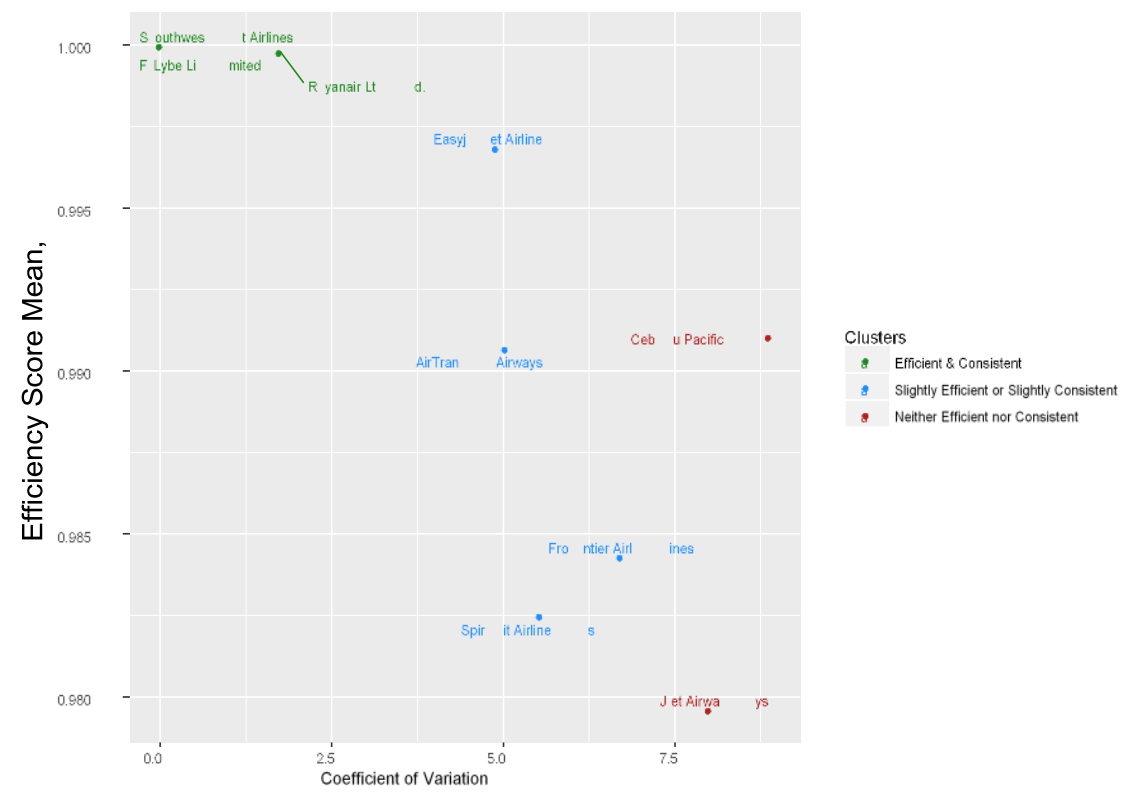

\section{Conclusion}

This research focuses on nine low cost carriers (LCC) by comparing their efficiencies. The term of efficiency can be specified as performance level of an airline. If efficiency level is consistent year by year, then it can be said that this airlines' can be shown as successfully operated. LCC strategy defines as minimum comfort level and minimum ticket fares with maximum efficiency. These airlines' implement low fare strategy and they gain from offtake of passengers. These airlines' mission is fulfilling the demand of short haul flights with presenting low fare ticket strategy. LCC model has been applied for the last approximately 25 years. The best LCC airline with its total number of fleet and strategy named as Ryanair changed its strategy and turned as a LCC in 1991. This year was the mainstay of the evolution of LCC airlines. Nowadays, airlines are separated in three ways. First of all, network strategy which is related with an airlines' primary mission is to operate as full service carrier and as a secondary strategy of LCC. Secondly, full service carrier airlines are used the method of high comfort level and in this way they are applied high ticket fares to their passengers. At last, LCC strategy is this research's issue, it is related with the airlines which are implemented low level comfort and low ticket fare strategy. There are two general subjects which specified the success of an airline. First of all, service level is a factor that include seat interval, seat width, maximum baggage policy, allowable baggage weight in cabin, in-flight cabin entertainment, number of toilet per person etc. These factors is about to measure comfort level applications. Service level is not a determining measurement value for LCC airlines. Secondly, in this research it 
is analyzed efficiency as a factor that include the parameters of the number of passengers carried (PC), passenger tonne kilometer performed in thousands (PTK), available seat kilometers (ASK) and passenger load factor (PLF). Only PC parameter is used as input, the other parameters are used as outputs. PLF parameter is ranged from 0 to 1 as a percentage, but the other parameters are immense numbers which can not suitable to operate unless a transformation such as natural logarithm. In figures which determines the efficiency level show that Ryanair, Southwest Airlines and Flybe Limited are efficient and consistent between the years of 2003-2013 as compared to other arlines. These airlines were firstly appeared in the LCC region in the beginning of 1990's and they were also structured in a more professional and planned model. They are applied lower prices then the other samples of LCC airlines. Easyjet Airlines, AirTran Airways, Frontier Airlines and Spirit Airlines are slightly efficient or slightly consistent between the years of 2003-2013. These airlines except Easyjet, started their operations afterwards then Ryanair and the other efficient and consistent airlines gave free rein to their positions to other LCC airlines. Easyjet is the most nearest airline which is also efficient and consistent then the other ones. Cebu Pacific and Jet Airways are neither efficient nor consistent between the years of 2003-2013. These airlines' ticket fares are not cheaper as efficient and consistent airlines and they also can not structured well as the other LCC airlines. Also their total number of fleet is not enough to be operated in a proper way and it is not suitable to compensate their passengers' demands.

The results may provide an insight to investors, public and also the owner of the airline. If an airline successfully operated, it shows persistence in terms of earnings, efficiency and other accounting measures. So, this airline can give a clear sign to investors or candidate investors to get shares of the airlines to increase shares to shareholders and other third party airlines that would like to make business with the airlines. In addition to these, owners of the airlines may take precautions to increase efficiency and make it stable over time. Owners of the airlines may also implement the used strategies in a proper way such as using the new strategies. Because LCC strategy is complicated to implement for airlines in a successful way.

In conclusion, after examining these nine LCC airlines, it is used the data envelopment analysis (DEA) methodology in this research. Besides DEA, after calculation of efficiency coefficients between the years of 2003-2013, CVs are calculated between years so as to analyze their efficiency models' consistency or variability. As it can be seen, future studies for network carriers and full service carriers are needed to examine their efficiency and consistency of efficiency in order to enlight the literature on airline industry in which such quantitative studies are relatively lack rather than other disciplines.

\section{Acknowledgements}

The author would like to thank the anonymous reviewers for their valuable suggestions that significantly improved the paper related with low cost transportation in civil aviation industry. 
Tüzün Tolga INAN

\section{References}

Adler, N., Golany, B., (2001). Evaluation of deregulated airline networks using data envelopment analysis combined with principal component analysis with an application to western europe. European Journal of Operational Research 132 (2), 260-273.

Alchian, A. A., (1965). Some economics of property rights. II politico, 816-829.

Alchian, A. A., Demsetz, H., (1972). Production, information costs, and economic organization, The American economic review 62 (5), 777-795.

Bailey, E. E., (1985). Airline deregulation in the united states: the benefits provided and the lessons learned. International Journal of Transport Economics/Rivista internazionale di economia dei trasporti, 119-144.

Bailey, E. E., Graham, D. R., Kaplan, D. P. Graham, D. P., (1985). Deregulating the airlines (Vol. 10). MIT press.

Barbot, C., Costa, A., Sochirca, E., (2008). Airlines performance in the new' market context: A comparative productivity and efficiency analysis. Journal of Air Transport Management 14 (5), 270-274.

Barros, C. P., Peypoch, N., (2009). An evaluation of european airlines' operational performance. International Journal of Production Economics 122 (2), 525-533.

Bennett, R. D., Craun, J. M., (1993). The airline deregulation evolution continues, The Southwest effect. Office.

Bhadra, D., (2009). Race to the bottom or swimming upstream: performance analysis of us airlines. Journal of Air Transport Management 15 (5), 227-235.

Boardman, A. E., Vining, A. R., (1989). Ownership and performance in competitive environments: A comparison of the performance of private, mixed, and state-owned enterprises. the Journal of Law and Economics 32 (1), 1-33.

Brown, C. A., (1980). A History of Aviation. Embry-Riddle Aeronautical University.

Caves, D. W., Christensen, L. R., Tretheway, M. W., (1979). US trunk air carriers, 1972-1977: A multilateral comparison of total factor productivity. University of Wisconsin-Madison, Social Systems Research Institute.

Caves, D. W., Christensen, L. R., Tretheway, M. W., (1984). Economies of density versus economies of scale: why trunk and local service airline costs differ. The RAND Journal of Economics, 471-489. 
Fethi, M. D., Jackson, P. M., Weyman-Jones, T. G., (2000). Measuring the efficiency of european airlines: an application of dea and tobit analysis.

Garcia, S., Cadarso, L., (2017). Airline re-fleeting managing revenues and maintenance operations. Transportation Research Procedia 27, 1121-1128.

Good, D. H., Nadiri, M. I., Roller, L. H., Sickles, R. C., (1993). Efficiency and productivity growth comparisons of european and us air carriers: a first look at the data. Journal of Productivity analysis 4 (1-2), 115-125.

Good, D. H., Roller, L. H., Sickles, R. C., (1995). Airline efficiency differences between europe and the us: implications for the pace of ec integration and domestic regulation. European Journal of Operational Research 80 (3), 508-518.

Hsu, C. I., Chao, C. C., Huang, P. S., (2013). Fleet dry/wet lease planning of airlines on strategic alliance. Transportmetrica A: Transport Science, 9(7), 603-628.

Kasper, D. M., (1988). Deregulation and globalization: Liberalizing international trade in air services. THE AMERICAN ENTERPRISE INSTITUTE TRADE IN.

Land K. C., Lovell, C. A. K., Thore, S., (1993). “Chance-Constrained Data Envelopment Analysis.” Managerial and Decision Economics 14 (6), 541-554.

Lee, B. L., Worthington, A. C., (2014). Technical efficiency of mainstream airlines and low-cost carriers: New evidence using bootstrap data envelopment analysis truncated regression. Journal of Air Transport Management 38, 15-20.

Millward, R., Parker, D. M., et al., (1983). Public and private enterprise: comparative behaviour and relative efficiency. Public sector economics, 199-274.

Niskanen, J., (2017). Bureaucracy and representative government. Routledge.

Olesen, O. B., Petersen, N. C., (1995). “Chance Constrained Efficiency Evaluation.” Management Science 41 (3), 442-457.

Oum, T. H., Yu,C., (1998). Cost competitiveness of major airlines: an international comparison. Transportation Research Part A: Policy and Practice, 32(6), 407-422.

Simar, L., Wilson, P. W., (2007). Estimation and inference in two-stage, semi-parametric models of production processes. Journal of econometrics 136 (1), 31-64.

Stasinopoulos, D., (1992). The second aviation package of the european community. Journal of Transport Economics and Policy 26 (1), 83-87.

Stasinopoulos, D., (1993). The third phase of liberalisation in community aviation and the need for supplementary measures. Journal of Transport Economics and Policy 27 (3), 323-328. 


\section{Tüzün Tolga iNAN}

Strassmann, P. A. (1990). The business value of computers: an executive's guide. Information Economics Press.

Vincent, D., Stasinopoulos, D., (1990). The aviation policy of the european community. Journal of Transport Economics and Policy 24 (1), 95-100.

Windle, R. J., Dresner, M. E. (1995). The short and long run effects of entry on US domestic air routes. Transportation Journal, 14-25.

Windle, R. J., (1991). The world's airlines: a cost and productivity comparison. Journal of Transport Economics and Policy, 31-49.

Whinston, M. D., Collins, S. C. (1992). Entry and competitive structure in deregulated airline markets: an event study analysis of People Express. The RAND Journal of Economics, 445-462.

\section{Appendix A}

Efficiency Scores of LCC

\begin{tabular}{|c|c|c|c|c|c|c|c|c|c|c|}
\hline Year & $N$ & CIL.C & Eff.C & ClH.C & CIL.V & Eff.V & CIH.V & CIL.N & Eff.N & CIH.N \\
\hline 2003 & 1 & 0.9747 & 0.9879 & 0.9850 & 0.9982 & 1.0000 & 0.9999 & 0.9747 & 0.9879 & 0.9854 \\
\hline 2004 & 1 & 0.9760 & 0.9876 & 0.9876 & 0.9978 & 1.0000 & 1.0000 & 0.9763 & 0.9876 & 0.9872 \\
\hline 2005 & 1 & 0.9775 & 0.9890 & 0.9890 & 0.9977 & 1.0000 & 1.0000 & 0.9778 & 0.9890 & 0.9887 \\
\hline 2007 & 1 & 0.9840 & 0.9934 & 0.9928 & 0.9959 & 1.0000 & 0.9997 & 0.9835 & 0.9934 & 0.9926 \\
\hline 2008 & 1 & 0.9864 & 0.9957 & 0.9941 & 0.9970 & 1.0000 & 1.0002 & 0.9862 & 0.9957 & 0.9939 \\
\hline 2009 & 1 & 0.9796 & 0.9902 & 0.9882 & 0.9993 & 1.0000 & 1.0007 & 0.9795 & 0.9902 & 0.9889 \\
\hline 2010 & 1 & 0.9828 & 0.9916 & 0.9906 & 0.9973 & 1.0000 & 0.9995 & 0.9824 & 0.9916 & 0.9905 \\
\hline 2011 & 1 & 0.9886 & 0.9916 & 0.9943 & 0.9976 & 1.0000 & 0.9996 & 0.9885 & 0.9916 & 0.9945 \\
\hline 2012 & 1 & 0.9873 & 0.9904 & 0.9932 & 0.9988 & 1.0000 & 1.0001 & 0.9873 & 0.9904 & 0.9933 \\
\hline 2013 & 1 & 0.9867 & 0.9896 & 0.9926 & 0.9964 & 1.0000 & 0.9994 & 0.9867 & 0.9896 & 0.9935 \\
\hline 2003 & 2 & 0.9654 & 0.9790 & 0.9786 & 0.9976 & 1.0000 & 1.0007 & 0.9656 & 0.9790 & 0.9788 \\
\hline
\end{tabular}




\begin{tabular}{|c|c|c|c|c|c|c|c|c|c|c|}
\hline 2004 & 2 & 0.9677 & 0.9807 & 0.9824 & 0.9963 & 1.0000 & 1.0012 & 0.9680 & 0.9807 & 0.9827 \\
\hline 2005 & 2 & 0.9711 & 0.9836 & 0.9850 & 0.9960 & 1.0000 & 1.0018 & 0.9711 & 0.9836 & 0.9849 \\
\hline 2007 & 2 & 0.9872 & 0.9974 & 0.9969 & 0.9943 & 1.0000 & 1.0013 & 0.9870 & 0.9974 & 0.9969 \\
\hline 2008 & 2 & 0.9769 & 0.9888 & 0.9893 & 0.9932 & 0.9953 & 0.9953 & 0.9770 & 0.9888 & 0.9892 \\
\hline 2009 & 2 & 0.9831 & 0.9952 & 0.9951 & 0.9975 & 1.0000 & 1.0029 & 0.9831 & 0.9952 & 0.9942 \\
\hline 2010 & 2 & 0.9876 & 0.9980 & 0.9979 & 0.9962 & 1.0000 & 1.0009 & 0.9872 & 0.9980 & 0.9984 \\
\hline 2011 & 2 & 0.9940 & 0.9990 & 1.0041 & 0.9963 & 1.0000 & 1.0007 & 0.9937 & 0.9990 & 1.0040 \\
\hline 2012 & 2 & 0.9945 & 0.9987 & 1.0028 & 0.9980 & 1.0000 & 1.0025 & 0.9941 & 0.9987 & 1.0030 \\
\hline 2013 & 2 & 0.9853 & 0.9902 & 0.9945 & 0.9891 & 0.9925 & 0.9923 & 0.9847 & 0.9902 & 0.9941 \\
\hline 2003 & 3 & 0.9803 & 0.9937 & 0.9920 & 0.9944 & 0.9959 & 0.9961 & 0.9805 & 0.9937 & 0.9928 \\
\hline 2004 & 3 & 0.9833 & 0.9943 & 0.9932 & 0.9939 & 0.9961 & 0.9964 & 0.9816 & 0.9943 & 0.9935 \\
\hline 2005 & 3 & 0.9843 & 0.9954 & 0.9947 & 0.9929 & 0.9954 & 0.9961 & 0.9829 & 0.9954 & 0.9955 \\
\hline 2007 & 3 & 0.9899 & 1.0000 & 0.9980 & 0.9953 & 1.0000 & 1.0003 & 0.9881 & 1.0000 & 0.9999 \\
\hline 2008 & 3 & 0.9878 & 0.9976 & 0.9955 & 0.9957 & 0.9976 & 0.9980 & 0.9856 & 0.9976 & 0.9975 \\
\hline 2009 & 3 & 0.9837 & 0.9941 & 0.9923 & 0.9953 & 0.9961 & 0.9990 & 0.9818 & 0.9941 & 0.9933 \\
\hline 2010 & 3 & 0.9881 & 0.9963 & 0.9947 & 0.9942 & 0.9967 & 0.9967 & 0.9861 & 0.9963 & 0.9956 \\
\hline 2011 & 3 & 0.9960 & 0.9986 & 0.9999 & 0.9965 & 0.9989 & 0.9988 & 0.9934 & 0.9986 & 1.0052 \\
\hline 2012 & 3 & 0.9967 & 0.9992 & 1.0005 & 0.9984 & 0.9994 & 0.9997 & 0.9942 & 0.9992 & 1.0047 \\
\hline 2013 & 3 & 0.9968 & 0.9993 & 1.0011 & 0.9961 & 0.9995 & 0.9994 & 0.9938 & 0.9993 & 1.0037 \\
\hline 2003 & 4 & 0.9798 & 1.0000 & 1.0003 & 0.9976 & 1.0000 & 1.0006 & 0.9802 & 1.0000 & 1.0004 \\
\hline
\end{tabular}


Tüzün Tolga INAN

\begin{tabular}{|c|c|c|c|c|c|c|c|c|c|c|}
\hline 2004 & 4 & 0.9822 & 1.0000 & 1.0013 & 0.9964 & 1.0000 & 1.0014 & 0.9824 & 1.0000 & 1.0009 \\
\hline 2005 & 4 & 0.9818 & 1.0000 & 1.0011 & 0.9961 & 1.0000 & 1.0014 & 0.9815 & 1.0000 & 1.0005 \\
\hline \multicolumn{11}{|c|}{ Efficiency Scores of LCC } \\
\hline Year & $N$ & CIL.C & Eff.C & ClH.C & CIL.V & Eff.V & ClH.V & CIL.N & Eff.N & CIH.N \\
\hline 2007 & 4 & 0.9819 & 1.0000 & 1.0053 & 0.9943 & 1.0000 & 1.0023 & 0.9817 & 1.0000 & 1.0038 \\
\hline 2008 & 4 & 0.9790 & 1.0000 & 1.0063 & 0.9970 & 1.0000 & 1.0006 & 0.9789 & 1.0000 & 1.0065 \\
\hline 2009 & 4 & 0.9787 & 1.0000 & 1.0034 & 0.9974 & 1.0000 & 1.0032 & 0.9791 & 1.0000 & 1.0038 \\
\hline 2010 & 4 & 0.9807 & 1.0000 & 1.0040 & 0.9961 & 1.0000 & 1.0010 & 0.9800 & 1.0000 & 1.0052 \\
\hline 2011 & 4 & 0.9838 & 1.0000 & 1.0070 & 0.9965 & 1.0000 & 1.0007 & 0.9834 & 1.0000 & 1.0065 \\
\hline 2012 & 4 & 0.9860 & 1.0000 & 1.0071 & 0.9976 & 1.0000 & 1.0035 & 0.9853 & 1.0000 & 1.0069 \\
\hline 2013 & 4 & 0.9846 & 1.0000 & 1.0074 & 0.9946 & 1.0000 & 1.0015 & 0.9844 & 1.0000 & 1.0068 \\
\hline 2003 & 5 & 0.9638 & 0.9762 & 0.9748 & 0.9982 & 1.0000 & 0.9999 & 0.9636 & 0.9762 & 0.9750 \\
\hline 2004 & 5 & 0.9705 & 0.9811 & 0.9810 & 0.9980 & 1.0000 & 0.9998 & 0.9707 & 0.9811 & 0.9813 \\
\hline 2005 & 5 & 0.9764 & 0.9849 & 0.9849 & 0.9977 & 1.0000 & 1.0001 & 0.9764 & 0.9849 & 0.9849 \\
\hline 2007 & 5 & 0.9763 & 0.9858 & 0.9855 & 0.9965 & 1.0000 & 1.0000 & 0.9766 & 0.9858 & 0.9855 \\
\hline 2008 & 5 & 0.9808 & 0.9892 & 0.9885 & 0.9970 & 1.0000 & 1.0001 & 0.9805 & 0.9892 & 0.9884 \\
\hline 2009 & 5 & 0.9745 & 0.9831 & 0.9816 & 0.9988 & 1.0000 & 1.0029 & 0.9745 & 0.9831 & 0.9815 \\
\hline 2010 & 5 & 0.9739 & 0.9824 & 0.9813 & 0.9967 & 1.0000 & 1.0000 & 0.9736 & 0.9824 & 0.9812 \\
\hline 2011 & 5 & 0.9794 & 0.9818 & 0.9829 & 0.9946 & 0.9968 & 0.9967 & 0.9794 & 0.9818 & 0.9829 \\
\hline 2012 & 5 & 0.9848 & 0.9875 & 0.9889 & 0.9979 & 1.0000 & 1.0024 & 0.9849 & 0.9875 & 0.9889 \\
\hline 2013 & 5 & 0.9891 & 0.9912 & 0.9940 & 0.9945 & 1.0000 & 1.0013 & 0.9892 & 0.9912 & 0.9936 \\
\hline 2003 & 6 & 0.9742 & 0.9889 & 0.9887 & 0.9976 & 1.0000 & 1.0008 & 0.9745 & 0.9889 & 0.9875 \\
\hline 2004 & 6 & 0.9759 & 0.9864 & 0.9856 & 0.9925 & 0.9946 & 0.9948 & 0.9759 & 0.9864 & 0.9858 \\
\hline 2005 & 6 & 0.9750 & 0.9855 & 0.9846 & 0.9919 & 0.9941 & 0.9944 & 0.9752 & 0.9855 & 0.9848 \\
\hline 2007 & 6 & 0.9641 & 0.9747 & 0.9750 & 0.9869 & 0.9905 & 0.9904 & 0.9639 & 0.9747 & 0.9748 \\
\hline
\end{tabular}


Eskişehir Osmangazi Üniversitesi Sosyal Bilimler Dergisi

\begin{tabular}{lllllllllll}
\hline 2008 & 6 & 0.9548 & 0.9678 & 0.9701 & 0.9969 & 1.0000 & 1.0009 & 0.9555 & 0.9678 & 0.9692 \\
2009 & 6 & 0.9668 & 0.9774 & 0.9765 & 0.9939 & 0.9944 & 0.9948 & 0.9667 & 0.9774 & 0.9764 \\
2010 & 6 & 0.9696 & 0.9792 & 0.9788 & 0.9923 & 0.9944 & 0.9941 & 0.9693 & 0.9792 & 0.9790 \\
2011 & 6 & 0.9734 & 0.9782 & 0.9856 & 0.9926 & 0.9946 & 0.9943 & 0.9734 & 0.9782 & 0.9848 \\
2012 & 6 & 0.9750 & 0.9797 & 0.9843 & 0.9932 & 0.9941 & 0.9943 & 0.9751 & 0.9797 & 0.9840 \\
2013 & 6 & 0.9733 & 0.9784 & 0.9832 & 0.9909 & 0.9941 & 0.9938 & 0.9733 & 0.9784 & 0.9833 \\
2003 & 7 & 0.9849 & 1.0000 & 0.9978 & 0.9977 & 1.0000 & 1.0006 & 0.9838 & 1.0000 & 0.9982 \\
\hline 2004 & 7 & 0.9850 & 1.0000 & 0.9984 & 0.9964 & 1.0000 & 1.0013 & 0.9839 & 1.0000 & 0.9993 \\
\hline 2005 & 7 & 0.9859 & 1.0000 & 0.9981 & 0.9958 & 1.0000 & 1.0011 & 0.9848 & 1.0000 & 0.9993 \\
\hline 2007 & 7 & 0.9902 & 0.9992 & 0.9978 & 0.9962 & 0.9997 & 1.0001 & 0.9888 & 0.9997 & 1.0003 \\
\hline 2008 & 7 & 0.9890 & 1.0000 & 0.9972 & 0.9972 & 1.0000 & 1.0000 & 0.9863 & 1.0000 & 0.9994 \\
\hline 2009 & 7 & 0.9875 & 1.0000 & 0.9976 & 0.9978 & 1.0000 & 1.0034 & 0.9840 & 1.0000 & 0.9991 \\
\hline 2010 & 7 & 0.9890 & 1.0000 & 0.9990 & 0.9965 & 1.0000 & 1.0000 & 0.9874 & 1.0000 & 1.0003 \\
\hline 2011 & 7 & 0.9939 & 0.9991 & 1.0057 & 0.9972 & 1.0000 & 1.0001 & 0.9921 & 0.9991 & 1.0075 \\
\hline
\end{tabular}

Efficiency Scores of LCC

\begin{tabular}{cccccccccccc}
\hline \hline Year & $N$ & CIL.C & Eff.C & CIH.C & CIL.V & Eff.V & CIH.V & CIL.N & Eff.N & CIH.N \\
\hline 2012 & 7 & 0.9939 & 0.9995 & 1.0047 & 0.9987 & 1.0000 & 1.0003 & 0.9932 & 0.9995 & 1.0066 \\
\hline 2013 & 7 & 0.9942 & 0.9997 & 1.0049 & 0.9960 & 1.0000 & 1.0004 & 0.9928 & 0.9997 & 1.0047 \\
& & & & & & & & & & \\
2003 & 8 & 0.9782 & 1.0000 & 1.0023 & 0.9976 & 1.0000 & 1.0006 & 0.9790 & 1.0000 & 1.0027 \\
2004 & 8 & 0.9794 & 1.0000 & 1.0023 & 0.9964 & 1.0000 & 1.0014 & 0.9799 & 1.0000 & 1.0025 \\
2005 & 8 & 0.9799 & 1.0000 & 1.0025 & 0.9961 & 1.0000 & 1.0015 & 0.9810 & 1.0000 & 1.0015 \\
\hline & & & & & & & & & & \\
\hline
\end{tabular}


Tüzün Tolga INAN

\begin{tabular}{|c|c|c|c|c|c|c|c|c|c|c|}
\hline 2008 & 8 & 0.9783 & 1.0000 & 1.0090 & 0.9969 & 1.0000 & 1.0005 & 0.9783 & 1.0000 & 1.0068 \\
\hline 2009 & 8 & 0.9793 & 1.0000 & 1.0042 & 0.9975 & 1.0000 & 1.0033 & 0.9791 & 1.0000 & 1.0034 \\
\hline 2010 & 8 & 0.9809 & 1.0000 & 1.0034 & 0.9961 & 1.0000 & 1.0007 & 0.9799 & 1.0000 & 1.0039 \\
\hline 2011 & 8 & 0.9835 & 1.0000 & 1.0064 & 0.9963 & 1.0000 & 1.0010 & 0.9842 & 1.0000 & 1.0080 \\
\hline 2012 & 8 & 0.9851 & 1.0000 & 1.0068 & 0.9976 & 1.0000 & 1.0037 & 0.9852 & 1.0000 & 1.0065 \\
\hline 2013 & 8 & 0.9851 & 1.0000 & 1.0076 & 0.9946 & 1.0000 & 1.0013 & 0.9848 & 1.0000 & 1.0074 \\
\hline 2003 & 9 & 0.9742 & 0.9844 & 0.9829 & 0.9976 & 1.0000 & 1.0007 & 0.9738 & 0.9844 & 0.9827 \\
\hline 2004 & 9 & 0.9721 & 0.9812 & 0.9818 & 0.9968 & 1.0000 & 1.0004 & 0.9720 & 0.9812 & 0.9822 \\
\hline 2005 & 9 & 0.9717 & 0.9799 & 0.9799 & 0.9962 & 1.0000 & 1.0015 & 0.9720 & 0.9799 & 0.9803 \\
\hline 2007 & 9 & 0.9748 & 0.9835 & 0.9836 & 0.9951 & 1.0000 & 0.9999 & 0.9752 & 0.9835 & 0.9838 \\
\hline 2008 & 9 & 0.9761 & 0.9843 & 0.9834 & 0.9968 & 1.0000 & 1.0008 & 0.9762 & 0.9843 & 0.9836 \\
\hline 2009 & 9 & 0.9692 & 0.9776 & 0.9760 & 0.9979 & 1.0000 & 1.0032 & 0.9693 & 0.9776 & 0.9761 \\
\hline 2010 & 9 & 0.9709 & 0.9788 & 0.9778 & 0.9962 & 1.0000 & 0.9999 & 0.9708 & 0.9788 & 0.9777 \\
\hline 2011 & 9 & 0.9807 & 0.9835 & 0.9849 & 0.9964 & 1.0000 & 1.0012 & 0.9806 & 0.9835 & 0.9849 \\
\hline 2012 & 9 & 0.9827 & 0.9852 & 0.9866 & 0.9986 & 1.0000 & 1.0003 & 0.9828 & 0.9852 & 0.9865 \\
\hline 2013 & 9 & 0.9834 & 0.9866 & 0.9911 & 0.9964 & 1.0000 & 1.0000 & 0.9835 & 0.9866 & 0.9913 \\
\hline
\end{tabular}


Notes:

- $\mathrm{CIL}$ and $\mathrm{CIH}$ stand for confidence interval of low threshold, confidence interval of high threshold.

- The capital letters after the variables with a"." C, V and $\mathrm{N}$ indicate returns to scales which are constant, variable and non-decreasing respectively for Robust DEA.

- All efficiencies are calculated with 1000 bootstrapped iterations to get robust coefficients.

- The low cost carriers studied here are 1: AirTran Airways, 2: Cebu Pacific, 3: Easyjet Airline, 4: Flybe Limited, 5: Frontier Airlines, 6: Jet Airways, 7: Ryanair Ltd., 8: Southwest Airlines, 9: Spirit Airlines. 